\title{
Pedagogy and Other Unfortunate Events: Cheerful Nihilism in Popular Children's Books
}

\author{
Rebecca-Anne C. Do Rozario
}

Teaching the difference between right and wrong has long been a pedagogical function ascribed to and demonstrated in children's books. Childhood itself is dominated by educational institutions, practices and theories; even the process of ageing is regulated by a child's schooling. Children's authors, perhaps as a consequence, often focus attention upon school, situating an articulation and dissemination of values within the educational sphere. Children's authors, however, sometimes reject imposed value constructions, creating nihilistic discourses with which to mock and rebuff pedagogical aims and practices. Lemony Snicket, for example, sends his unfortunate protagonists, the Baudelaire orphans, to boarding school in the fifth book of $A$ Series of Unfortunate Events, The Austere Academy (2000). The orphans' initial impression of the 'pointless' (2000, p.4) physical exercises endured by the students is confirmed by their observation that the Prufrock Preparatory School's motto is 'Memento Mori,' or 'Remember you will die' (2000,p.13). Lemony Snicket, like J.K. Rowling and Eoin Colfer, sees nothing incongruous in the simultaneous experiences of education and death, oblivion or general meaninglessness. This paper examines nihilistic discourses elaborating pedagogy as explored in popular, contemporary children's narratives, analysing movements between pessimism and optimism or, in fact, what can be interpreted as cheerful nihilism.

Anne Scott MacLeod argued in 1976: 'In a number of recent books written for children, beneath the affirmative philosophy which traditionally has been regarded as an appropriate convention in children's books, there runs an undercurrent of pessimism' (1976, p.96). Citing, for instance, the shrews' territorial war in Russell Hoban's The Mouse and His Child (1967), with its series of apparently meaningless deaths, and the 'evil of nihilism' (1976, p. 101) in Madeleine L'Engle's $A$ Wind in the Door (1973), MacLeod came to the conclusion that 'through the images and emotional tone of the writing' such authors reveal 'that the present world is an ugly, threatening place tobe'(1976,p.102). This conclusion is not in and of itself entirely nihilistic. For instance, nihilism in The Mouse and His Child relates much more to a premise of meaninglessness, implicit in C. Serpentina's examination of the 'Last Visible Dog'. The latter is a metaphorical dissertation based upon a dog food label with repeated, apparently endless, patterns of dogs carrying the labelled cans, that (at least to C. Serpentina) signifies the quest for the ultimate truth. The label inspires his piece of absurdist playwriting, which, according to a thespian crow, 'means anything and everything' (1976, p. 68). This potential profusion of meaning in fact negates any useful meaning. Once the mouse child reveals that the last dog on the label is nothing, C. Serpentina concludes: 'Nothing is the ultimate truth'(1976,p.115). The child nonetheless seeks 'the other side of nothing' by removing the label, corresponding to a common thread in nihilistic discourses in children's literature (1976, p. 115). There is no halt at nihilism, but a look beyond, seeking what lies behind meaning's oblivion.

Nihilism has been an undercurrent of earlier literature aimed at children. Lewis Carroll's Alice's Adventures in Wonderland contains several nihilistic references, beyond the overall supposition that nonsense itself, being ultimately a nullification of sense, invokes nihilism by virtue of its essentialmeaninglessness. Alice, for instance, contemplates a loss of existence when she first drinks from the bottle and shrinks: 'for it might end, you know [...] in my going out altogether, like a candle. I wonder what I should be like then?' (2000, p.17). Curiously, Alice ponders the paradox of retaining being simultaneously with potential non-existence, very much resisting a nihilistic conclusion, much as the mouse child seeks what lies beyond nothing. Alice's insistent identification and then rejection of meaninglessness culminates in the court room scene, during which the White Rabbit delivers a rewritten form of one of Carroll's own nonsense verses, 'She's All My Fancy Painted Him' (Gardner in Carroll 2000, p.122), and Alice responds: ' $I$ don't believe there's an atom of meaning in it' (2000, p.122). Alice effectively denies not only meaning, but the physical existence of the verses if one chooses, in Carrollian spirit, to take atom literally as a particle of matter. In the end, however, she re-imposes meaning upon the inhabitants of Wonderland: 'You're nothing but a pack of cards'(2000,p.124). She acknowledges the nothingness of the nonsense and overwrites it with the dominant signthing relationship. They represent and therefore are a pack of cards. Their existence as anything else is 'nothingness.' Alice explores multiple positions, asserting, resisting and moving beyond nihilism. 
So far much of the engagement of children's literature with nihilism has related to the act of 'making sense.' The pedagogical baggage that the genre carries necessitates an emphasis upon how this act takes place under institutional auspices. Carroll mocks didactics: Alice's learned verses turn into nonsense, the Mock Turtle's educational programme devolve into a series of puns, and lessons themselves become a lessening into nothingness. The Mock Turtle explains that lessons decrease by an hour a day. Alice surmises: 'Then the eleventh day must have been a holiday?' (2000, p.99). However, as when she shrinks, she debates what comes after nothing: 'And how did you manage on the twelfth?' (2000, p. 99). Alice strives to discover the other side of nihilism; in this case, the other side of the non-existence of lessons. Alice, like many protagonists in children's literature, does not rest at the nihilistic conclusion, but questions what lies beyond the nullification of meaning and existence.

Other children's books operate in the tension between the reaffirmation of meaning and nihilism, the tension itself affording a strange pleasure for readers. Lemony Snicket's series of books, A Series of Unfortunate Events, consistently reiterates that the narrative journey of the Baudelaire orphans is 'extremely unpleasant' (1999). The denial of pleasure, however, produces a nihilistic pleasure. Snicket's name is Daniel Handler, and his first novel, The Basic Eight (1999), is about teenagers in high school. A Guardian article on Lemony Snicket indicates that HarperCollins editor, Susan Rich, 'read The Basic Eight and decided, despite the sex, violence and absinthe, that Handler should write for young people' (Echlin 2002). That Handler's potential as a children's author was thus identified appears, on the surface, unlikely, but as Maria Tatar points out, fairy tales were originally filled with sex and violence (2003), and there is a pleasure in the shocking, appalling and indeed nihilistic that carries through Handler/Snicket's A Series of Unfortunate Events. Handler inserts himself into the events as author under the pseudonym, denying the reality of his authorship while simultaneously participating in the unwinding narrative as the unreal author. In effect, as Lemony Snicket makes meaning, or perhaps more accurately, conspiracy, Daniel Handler simultaneously renounces it in a cheeky nihilistic gesture.
The Baudelaire children are introduced in the series enjoying the beach on a rainy day. The book is called $A$ Bad Beginning (1999) and so within a few pages, the aptly named Mr Poe arrives to tell the children that their parents are dead: 'They perished [...] in a fire that destroyed the entire house. I'm very, very sorry to tell you this, my dears' (1999, p.8). To readers acquainted with the French poet, the orphan's surname indicates that the children will suffer and suffer they do. They are given into the care of ogrish Count Olaf - 'His eyes were very, very shiny, which made him look both hungry and angry' (1999, p.22) - who attempts to steal their fortune by suspending the baby, Sunny, from a tower to force the eldest, Violet, into marrying him. Snicket chiefly utilises the threat and implication of violence and delights in the grotesque and monstrous. Count Olaf, the series' villain, is a character evolved from the ogres and bogey men of fairy tale, a sinister presence who snatches babies and puts them in cages and attempts to marry innocent young girls. He even heads a carnivalesque theatre troupe, including women in 'bright white powder,' a man who had 'two hooks instead of hands,' and one 'who looked like neither a man nor a woman' (1999, pp.47-48). Treated as servants, left to sleep in the attic, and given cold porridge for breakfast, the children experience many of the depravations and horrors of their predecessors at the hands of various ogres in fairy tale. Yet, as Marina Warner notes: 'One of the most profound and puzzling features of the bogeyman is his seductive power: he can charm at the same time as he repels' (2000, p.167). This feature becomes quite explicit with the casting of Hollywood star, Jim Carrey, as Olaf in the film adaptation (2004), the comedy actor turning the bogeyman into a seductive marketing coup.

The charm of the sinister, with its inherent sense of contradiction in the meeting of appeal and threat, corresponds to the manner by which this strain of children's literature develops an awareness of, and response to, nihilism. It generates a cheerful nihilism, which is, according to Richard Boyd Hauck, 'to laugh in spite of a clear recognition that creation may mean nothing' (1971, p.xi). However, as John Marmysz suggests, it might more accurately be to laugh because there is no meaning: 'it makes little sense to take things too seriously, even our own frustrations and failures. The humorous response to 
nihilism brings this insight forth and challenges nihilists to take their own world view to heart' (2003, p.124). Pleasure is thus achieved in nihilistic conclusions: if, as Lemony Snicket seems to suggest, things will certainly get worse and everything you've known in your life be wiped out, one might as well take pleasure in the experience. Certainly, by the twelfth book, The Penultimate Peril (2005), the Baudelaires realise 'they did not know if their own observations, errands and deeds meant that they were noble, or wicked, or somewhere in between' (2005, p.339). Their value system becomes increasingly meaningless as they are unable to properly distinguish between good and evil and thus they cease to be able to make meaning out of their experience. There is a pleasure in their predicament for the reader, understood by Lemony Snicket who recommends on the back cover that the book itself be put back by the hopeful reader, since it offers 'misery, despair, and unpleasantness'(1999). Unadulterated nihilistic despair is incongruously packaged for pleasure. Of course, like Alice's Adventures in Wonderland, the series persists in going beyond the nihilistic conclusion. At the end of The Penultimate Peril, the Baudelaires contemplate 'who they might become' (2005, p.353) even after the meanings that have formulated their existence have been questioned and destroyed. Despite proofs and tones that would suggest otherwise, the response is optimistic.

Marmysz argues for a reassessment of nihilism to include a type of nihilistic response embedded in humour and optimism. He argues that nihilism does embrace ideals or absolutes that cannot be found in existence: 'In nihilistic incongruity [...] we find a situation in which the nihilist must forever fail in the pursuit of that which is most valuable and dearly desired' (2003, p.111). Although the conventional battle between good and evil has not become obsolete, contemporary children's authors tend to serialise a cheeky, although sometimes ironic and sometimes anguished, delight in this nihilistic incongruity, acknowledging that good and evil are inevitably hollow absolute constructions. J.K. Rowling's Harry Potter series queries absolutes in Harry's struggles against the evil embodied in Voldemort and the Death Eaters, an interrogation taking place within the generic conditions of the boarding school novel with its pedagogical implications. When confronted with a 'foul' replacement Headmistress, Professor Umbridge, he suggests to his guardian, Sirius Black, that she must consequently be a Death Eater: “but the world isn't split into good people and Death Eaters,' said Sirius with a wry smile' (2003, p.271). His observation dryly acknowledges that not all awful people follow the same ideals. Sirius himself, unjustly convicted of mass murder and having grown up in a family supportive of Voldemort, is a sardonic portrait of goodness, frustrated in the achievement of his own ideals, who fails at the end of the fifth novel when he dies at the hands of the Death Eaters.

Rowling, however, likewise promotes comical laughter in nihilistic incongruity through her depiction of the Weasley twins. Fred and George are practical jokers who continuously break the rules at Hogwarts School of Witchcraft and Wizardry. They respond to the increasingly meaningless, bureaucratic regulations imposed by Umbridge by ostentatiously breaking the rules in a series of outlandish practical jokes. They undertake the nihilistic experience: 'We don't care about staying any more' (2003, p.553). Having turned part of the school building into a swamp, they then depart Hogwarts by flying into the sunset, celebrating their rejection of formalised education in heroic style. When in Harry Potter and the Half-Blood Prince (2005), Voldemort is terrorising the wizarding community, the twins, ostensibly on the side of good, reject the value absolutes and administrative impositions, capitalising upon the humour inherent in the nihilistic incongruity. On Diagon Alley, where all the shop windows are filled with pamphlets providing the latest government security advice, 'Weasleys'Wizard Wheezes' stands out gaudily ludicrous, for along with astounding merchandise:

The right-hand window was covered with a gigantic poster, purple like those of the Ministry, but emblazoned with flashing yellow letters:

\footnotetext{
Why Are You Worrying About You-Know-Who? You SHOULD Be Worrying About U-NO-POOthe Constipation Sensation That's Gripping the Nation!

(2005, p.113).
}

Hauck sees cheerful nihilism in such manifestations where 'the awareness of total absurdity - sees everything 
as absurd. This all-encompassing view is paradoxical: it sees that there is no norm, that everything deviates from a man's inner sense of rightness or his suspicion that there should be ultimate meaning' (1971, p.4). The twins are masters of this awareness, responding to terrorism with jokes that themselves terrorise in a carnival of deviance. All is terror and all is meaningless.

Child readers may relish the gradual destruction of meaning while retaining the awareness of 'nihilistic longing' that, as Marmysz argues 'keeps the nihilist oriented in the right direction while at the same time creating the sort of distance that allows the nihilist to behold and fully appreciate the import of the highest objects of desire' (2003, p.111). Marmysz might just be writing about Rowling's creation, the Mirror of Erised, in which one can see the reflection of one's greatest desires, but must learn to understand and accept that they do not show what is real and attainable. As the name suggests, it is not a truthful depiction of desire, merely a mirror image. Professor Dumbledore, Hogwarts' principal and Harry's mentor, acknowledges the value of nihilistic incongruity in understanding such magical mirrors: 'this mirror will give us neither knowledge or truth. Men have wasted away before it, entranced by what they have seen, or been driven mad, not knowing if what it shows is real or even possible' (1997, p.157). Harry, for example, sees his family surrounding him. As his family members have already died, the desire for his ideal family can never attain actual, perfect existence. Dumbledore says that he only ever sees socks in the mirror. His expression of regret at never receiving what he views as the ideal gift gives an inkling as to the humour capable of manifesting in a philosophy that has usually been seen as irredeemably negative and pessimistic.

Yet, while attainment of ideals is unachievable, and laughter serves as a response, Rowling also highlights the darker side of the attempt to realise such ideals. Thomas S. Hibbs suggests, 'if, as is true of Voldemort, we separate valour from the common good, from justice and friendship, then we are left with nihilism, the empty expression of power for its own sake-a position advocated explicitly by Voldemort' (2005). Courage is likewise a key value associated with Gryffindor, the school house to which Harry and his friends, Ron and Hermione, belong. Each house has certain values attributed to it: cunning, hard work, cleverness, for example. Voldemort's ambition is enshrined in the house to which he belonged, Slytherin. However, these independent values are closely associated with the values of community and friendship at Hogwarts. At the conclusion of Harry Potter and the Philosopher's Stone, for instance, Dumbledore rewards fellow Gryffindor student, Neville, stating: 'There are all kinds of courage [...] It takes a great deal of bravery to stand up to our enemies, but just as much to stand up to our friends' (1997, p.221). Courage for its own sake lacks meaning, but the courage exercised by Neville in this case is openly linked to the good of Gryffindor as a whole and to friendship. He attempts to prevent Harry and his friends, Ron and Hermione, from breaking school rules, asserting himself as Ron had previously advised him: 'You can't go out [...] you'll be caught again. Gryffindor will be in even more trouble' (1997, p.198). Neville's concern for Gryffindor, however, likewise highlights the inherent contradiction in the magical educational institute. The competition between houses to win the house cup at the end of the academic year threatens to render the values taught void. Thus, at the beginning of Harry Potter and the Order of the Phoenix (2003), the Sorting Hat, which magically assigns new students to their houses, warns against the divisions caused by the contending, independent values of the houses: 'Though condemned I am to split you/ Still I worry that it's wrong [...] I wonder whether Sorting/ May not bring the end I fear' (2003, p.186). The Hat's nihilistic concern is valid.

Harry Potter and the Order of the Phoenix focuses upon the contradictions and impossibilities that create nihilistic frustration. Sources of authority embedded in wizard bureaucracy are revealed as corrupt and the media is shown to promote lies and rumours, rendering journalistic integrity void. The journalist Rita Skeeter confirms: 'The Prophet exists to sell itself' (2003, p.501). Indeed, it is only The Quibbler, a conspiracy based tabloid, that ultimately prints Harry's true story. It is no surprise that in this volume, Harry experiences a nihilistic phase. On a personal level, Harry discovers that his father and his childhood friends, Lupin and Sirius, whom Harry views as heroes, were as Sirius says, 'sometimes arrogant little berks' (2003, p.591). The behaviour of his father as a teenager 
contradicts what Harry has been told of his goodness, temporarily rendering his faith in his father meaningless. These events notwithstanding, as in other books in the series, Harry leads his friends in battle against the minions of Lord Voldemort. It is one of several encounters already played out, but focuses upon Harry's attempts to, and even refusals to, embody courage in light of Voldemort's return, resulting in Harry's increasing alienation from his social network, this being one of Rowling's most challenging books in the series for its unflattering rendering of the teenage wizard. In this battle, his guardian, Sirius Black, is killed. Sirius's death prompts a clear, indeed capitalised, nihilistic outburst from Harry: 'I WANT OUT, I WANT IT TO END, I DON'T CARE ANY MORE' (2003, p.726). The values he has struggled to embody have isolated and failed him. Dumbledore's suggestion - 'You care so much you feel as though you will bleed to death with the pain of it' (2003, p.726) - articulates the violence of this grieving, existential angst, Harry wanting to 'shatter that calm old face, shake him, hurt him' after having wrecked havoc in his office (2003, p.726). That the hero of the series can be driven to a desire to end existence presents the possibility of a nihilistic response to the lost ideal of valour.

The series destabilises the absolute binaries of values, too, resisting clear portrayals of good heroes and evil villains. Malfoy is Harry's school nemesis, but the two are not aligned with the absolutes of good and evil. While Rowling, of course, only suggests nihilism in elements of her writing, she does consistently query and deny these extremes. Harry correctly suspects Malfoy of a plan to assassinate the principal, but when they engage in a duel Harry uses an unknown hex on him, one found written in the margins of his second-hand Potions textbook: 'Blood spurted from Malfoy's face and chest as though he had been slashed with an invisible sword. He staggered backwards and collapsed on to the waterlogged floor with a great splash' (2005, p.489). The violence is graphic - Malfoy 'shaking uncontrollably in a pool of his own blood' (2005, p.489) - and horrifies Harry. Nor is the violence simply magicked away, but is staunched by Professor Snape, who ironically invented the hex and noted it in the textbook when an unpopular schoolboy. Even 'good guys' like Harry, with the best intentions in the world, but a potentially lethal wand or textbook in hand, can perpetuate horrific, even vindictive violence. Even 'bad guys' like Malfoy and Snape may be innocent victims or rescuers. Meaning is embedded in the action rather than the value or purpose.

Marmysz argues: 'the problem of nihilism strikes only when an individual passionately desires ultimate meaning, value, and purpose, but believes those things to be out of reach' (2003, pp.84-85). This description is true of the Harry Potter series, from the moment Harry becomes The Boy Who Lived, but is left in the care of uncaring relatives, to the death of his mentor, Dumbledore. Yet the last words of Harry Potter and the Half-Blood Prince are: 'he felt his heart lift at the thought that there was still one last golden day of peace left to enjoy with Ron and Hermione' (2005, p.607). The books themselves are not nihilistic, and often find optimistic recourse to nihilism in school friendships and social networks, even though didactic efforts to control values and students may be rendered meaningless. Popular children's books like Harry Potter reveal the ability of the younger members of society to laugh at the vanity of ideals and horrors, recognising and revelling in the terror and violence that weave indiscriminately through the serialised battles between ultimately barren concepts of good and evil.

Terry Pratchett's cheerful nihilistic world view infiltrates at least one of the popular Discworld series marketed to children, The Wee Free Men (2003), which engages in anarchic dialogue with such children's classics as C. S. Lewis' The Lion, The Witch and the Wardrobe (1950). The book features nine year old Tiffany, an upcoming witch who, although bartering for the odd lesson from the travelling teachers with a vegetable, sensibly dismisses the pedagogical establishment as an institution. She learns from Mistress Weatherwax: 'The thing about witchcraft $[\ldots]$ is that it's not like school at all. First you get the test, and then afterwards you spend years findin' out how you passed it. It's a bit like life in that respect' (2003, p.306). There is no school for witches - such a school would be meaningless. The statement likewise infers that school is not like life. When Tiffany's sweetie-obsessed baby brother is kidnapped by a wicked elf, a riff on the White Witch's seduction of Edmund with Turkish Delight in Lewis' book, this clearly constitutes her test. Tiffany often finds Wentworth objectionable and sometimes wants him to 
disappear, undercutting any notions of idealised heroism on her part, but nonetheless sets off with a frying pan and the assistance of the Nac Mac Feegles, tiny, redheaded pixies in kilts. A toad informs Tiffany that the Feegles are rebels: 'Rebels? Against who?' 'Everyone. Anything' (2003, p.77). The Feegles are cheerfully nihilist, famous for 'stealin' an' drinkin' an' fightin"' (2003, p.91), rejecting rules except those enforced by the hag or kelda, both female matriarchal posts that Tiffany consequently fulfils. Tiffany does get her brother back, but does not attempt to change the Feegles by utilising her authority. She settles for making cheese and, like her Granny Aching, refuses any official, bureaucratic role. There is a certain nihilist edge to her thinking that prompts her to reject the institutionalised practice of authority and absolute values: 'it seemed to her that there were times when things didn't divide easily into 'true' and 'false' (2003, p.67).

Pratchett's comic, nihilistic flashes are among the influences upon Eoin Colfer, who has refined an intertextual blending of folklore violence and contemporary intrigue in the Artemis Fowl series. In an interview for the Guardian, the Irish Colfer referred to his childhood fairy drawings: 'I was into fairies with axes; I was never into them flitting round the garden. Because the fairies of Irish mythology are not like that at all, they are very warlike. Always up for a fight' (Rabinovitch 2005). They sound like the Feegles, close Celtic cousins, with red hair and brown skin. The heroine, Holly, is a leprechaun - that is LEPrecon, the special ops unit of the Lower Elements Police - and although she no longer swings axes, she and her colleagues tote tri-barrelled blasters, buzz batons, snubnosed lasers and biological bombs. The mix of ancient Irish mythology and James Bond-inspired gadgetry and arsenals - Colfer even has his own Q in the form of Foaly, a centaur genius - has made Colfer a best seller. The anti-hero for whom the series is named is a teenage criminal mastermind, the bane of the Lower Elements where the fairy creatures live in guarded isolation from humans. However, if, as Margery Hourihan argues, 'James Bond evolved as a representative of civilization, reason, order and freedom - and of the new consumerism of the West' (1997, p.21), Artemis as Bond's progeny reveals a nihilist undercurrent in the new consumerism, still wearing Armani suits in exotic locations, but uneasily aware of the ultimate meaninglessness of wealth accumulation and cut-throat business, values informing Western reason and order. Artemis' scheming consequently becomes something of a cheerful game in which Artemis flouts multiple levels of authority.

Colfer, a former teacher, confirms he 'drew mostly on the kids I was teaching' (Rabinovitch 2005) and, perhaps not ironically, the pedagogical is one level of authority Artemis rejects. Aself-styled genius at St Bartleby's School for Young Gentlemen, he retires school counselors at an alarming rate while publishing in major academic journals under a series of comic pseudonyms that mock, while contributing to, academic practices (2002b). Moreover, he cavalierly dispenses with parental authority, his father having disappeared, his mother disassociated from reality at the beginning of the series. The Epilogue of Artemis Fowl (2002a), a pseudo-commentary on the fairy case files concerning Artemis, incorporates a tongue-in-cheek dismissal of the concept of the Romantic innocent child, playing on the dualism Hibbs notes 'between celebrating inviolable innocence and seeing youth as predatory villains' (1999, pp.44-45) that in part influences nihilism: 'There is a tendency to romanticize Artemis. To attribute to him qualities that he does not posses. The fact that he used his wish to heal his mother is not a sign of affection. He did it simply because the Social Services were already investigating his case, and it was only a matter of time before he was put into care' (2002a, p.279). However, the peculiarity of Artemis Fowl as part child nihilist is that on the brink of the most radical nihilistic act of denying existence, perversely anything exists, even fairies and magic. Thus children's series like Artemis Fowl and Harry Potter fairly bulge with imagined populations even as their very existence is threatened: in this case, Artemis threatens to reveal to the world the truth about the Lower Elements, thus destroying the fairy population.

What finally disturbs Artemis' intellectual nihilism is violence itself, a violence that plays as distinctly intertextual, drawing, as earlier suggested, on ancient traditions and contemporary Hollywood tropes. Artemis' Eurasian bodyguard, Butler, is the most explicitly violent figure, adapt at martial arts, handy with big weapons and dressed in well-cut suits. He is a cross between Jackie Chan, 
Bruce Willis and Sean Connery. In a fight with a troll, he is thrown into a wall 'at a speed human bones were never meant to withstand,' (2002a, p.226) after which, saved from death by fairy magic, he takes on the troll wearing Medieval armour and swinging a mace, Colfer once again invoking ancient violence in contemporary intrigue. Yet, it is eventually Butler and Holly's violent near misses with death that encourage Artemis back from the nihilist brink, only for him to be replaced in Artemis Fowl: The Opal Deception (2005) by the evil pixie mastermind called Opal Koboi, a pretty childlike creature happy to destroy anything and anyone in pursuit of her own gain, or the threatened end of a demon world in Artemis Fowl and the Lost Colony (2006).

And thus children clamour for the next Unfortunate Event, or any one of the other best sellers tackling pedagogy with nihilistic verve. With both pessimistic and optimistic perspectives, and resistance to lasting non-existence, these expressions of nihilism challenge the realities of authority, and the possibilities of ideals imparted, through educational auspices, but in a way that is not always pessimistic. Children's literature has long been placed under pedagogical authority, making the often cheerful nihilism evidenced by these authors an almost inevitable response.

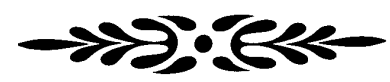

\section{REFERENCES}

Carroll, Lewis (2000) The Annotated Alice: The Definitive Edition. Intro. and notes by Martin Gardner. New York, Norton.

Colfer, Eoin (2002) Artemis Fowl. London, Puffin Books.

Echlin, Helena (2002) 'Dark Star', in Guardian Unlimited (on-line), August 21.

Hauck, Richard Boyd (1971) A Cheerful Nihilism: Confidence and 'The Absurd' in American Humorous Fiction. Bloomington/London, Indiana University Press.

Hibbs, Thomas (1999) Shows About Nothing: Nihilism in Popular Culture from The Exorcist to Seinfeld. Dallas, Spence.
Hoban, Russell (1976) The Mouse and His Child. Puffin, Ringwood, Vic.

Hourihan, Margery (1997) Deconstructing the Hero: Literary theory and children's literature. London, Routledge.

MacLeod, Anne Scott (1976) "Undercurrents: Pessimism in Contemporary Children's Fiction," Children's Literature in Education, 21: 96-102.

Marmysz, John (2003) Laughing at Nothing: Humour as a Response to Nihilism. Albany, SUNY.

Pratchett, Terry (2003) The Wee Free Men. London, Doubleday.

Rabinovitch, Dina (2005) 'Author of the month: Eoin Colfer', Guardian Unlimited (on-line), June 29.

Rowling, J.K. (1997) Harry Potter and the Philosopher's Stone. London, Bloomsbury. (2003) Harry Potter and the Order of the Phoenix. London, Bloomsbury. (2005) Harry Potter and the Half-Blood Prince. London, Bloomsbury.

Snicket, Lemony (1999) The Bad Beginning. New York, HarperCollins. (2000) The Austere Academy. New York, HarperCollins. (2005) The Penultimate Peril. New York, HarperCollins.

Tatar, Maria (2003) The Hard Facts of the Grimm's Fairy Tales. $2^{\text {nd }}$ edition. Princeton, Princeton UP.

Warner, Marina (2000) No Go The Bogeyman: Scaring, Lulling and Making Mock. London, Vintage.

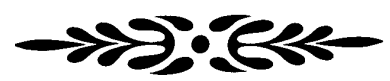

\section{BIOGRAPHICAL NOTE}

Rebecca-Anne C. Do Rozario teaches children's and fantasy literature at Monash University. She has published articles on fairy tale, musical theatre, children's and fantasy literature and animation. 